\title{
Pengaruh Poster Terhadap Perubahan Perilaku Penjamah Makanan Di Kantin Politeknik Negeri Jember
}

\author{
Muhammad Iqbal ${ }^{1 *}$, Nina Agusti Winarsih ${ }^{2}$ \\ 1,2 Jurusan Kesehatan, Politeknik Negeri Jember \\ iqbalbasagili@polije.ac.id*
}

\begin{abstract}
Hygiene sanitation of food in the canteen is important because of the existence of a canteen to ensure the health of canteen users. The behavior of food handlers determines the quality of food served. During this time there were still many cases of food handlers who lacked good behavior as food handlers. This study aims to improve the behavior of food handlers in the Jember State Polytechnic canteen using poster media without counseling. This research is a quasi-experimental study with the design of one group pretest posttest. Respondents from this study came from 10 food stands at the Jember State Polytechnic canteen. The first month was given a pretest and poster installation. Then the poster was left for 2 months and posttest. Data retrieval uses a behavior checklist form that has been validated. The results of statistical analysis show that the value of $p=0.9981$ which means $>$ 0.05 (alpha). That is, there were no significant changes between before and after the poster was given. This means that giving posters without counseling was not effective in changing the behavior of food handlers for the better. Viewed from the poster media itself there are no problems. However, explanations such as short presentations or counseling are needed so that food handlers change their behavior.
\end{abstract}

Keywords: Canteen, Counseling, Food Handler Behavior, Posters

\section{PENDAHULUAN}

Pada tahun 2017, keracunan R responden (100\%) menyentuhkan tangan disebabkan oleh minuman menduduki ke wajah, rambut dan lain-lain saat bekerja peringkat pertama yaitu 814 data dan dan ini merupakan kebiasaan paling buruk dikarenakan makanan menduduki (Siau dkk., 2015). Pada penelitian lain, peringkat ketiga yaitu 507 data (BPOM, 2017). Sebanyak 49\% dari 14 kios (terdiri dari kantin, restauran, kafetaria, fast food, terdapat 5 orang $(83,3 \%)$ berbicara saat melakukan pengolahan makanan dan 4 orang $(66,7 \%)$ belum memakai celemek dan kios pinggir jalan) pemilik kios ketika bekerja serta seluruh responden (6 mengizinkan orang sakit untuk mengolah orang) tidak memakai sepatu saat sedang makanan (Onyeneho dan Hedberg, 2013). bekerja. Hal ini juga disebabkan

Dari 64 food court (286 penjamah penyediaan APD yang kurang lengkap makanan) di Putrajaya, Malaysia, semua (Fatmawati dkk., 2013). Sebesar 66,7\% 
dari penjamah makanan pada 3 bulan terakhir mengalami minimal satu jenis penyakit menular (Syafirah dan Andrias, 2017).

Berdasarkan permasalahan di atas, diperlukan suatu media untuk meningkatkan ketaatan perilaku penjamah makanan. Media dapat dijadikan sebagai penyalur pesan atau informasi. Penggunaan media dalam bentuk kontekstual dapat digunakan untuk mengetahui suatu mutu keberhasilan pencapaian (Rahmaniati, 2015). Salah satu media yang dapat digunakan yaitu poster. Poster sendiri selain sebagai sarana penyalur informasi atau pesan, juga memiliki peranan dalam mengajak memperkenalkan sesuatu, atau memberi saran kepada orang lain (Rahmaniati, 2015).

Penelitian ini dilakukan di kantin Politeknik Negeri Jember karena aspek keterjangkauan. Selain itu di tempat penelitian belum pernah dilakukan penelitian dan para penjamah di kantin Politeknik Negeri Jember belum pernah mendapatkan pengetahuan dan terpapar informasi tentang Hygiene sanitasi makanan. Sehingga pemberian poster tentang hygiene sanitasi makanan ini bertujuan untuk meningkatkan perilaku penjamah makanan di kantin. Hal tersebut yang mendorong peneliti melakukan penelitian tentang efektivitas penggunaan media poster terhadap peningkatan ketaatan perilaku penjamah makanan.

\section{METODE PENELITIAN}

Penelitian ini merupakan penelitian quasi experimental design (eksperimen semu) dengan rancangan one group pretest posttest. Rancangan one group pretest posttest ini untuk mengetahui keefektifan media poster dalam meningkatkan ketaatan perilaku penjamah makanan tanpa adanya penyuluhan.

\section{Metode Pengumpulan Data}

Populasi dalam penelitian ini adalah seluruh penjamah makanan di kantin utama Politeknik Negeri Jember. Teknik pengambilan sampel menggunakan total sampling. Besar sampel pada penelitian ini adalah 14 orang dari 10 stand makanan. Pada penelitian ini data dikumpulkan melalui wawancara dan pengisian form checklist perilaku penjamah makanan. Media utama yang digunkan yaitu poster yang ditinggal selama 2 bulan sebagai intervensi setelah dilakukan wawancara dan pengisian form.

\section{Metode Analisis Data}

Variabel yang diteliti dalam analisis ini adalah perilaku penjamah makanan. Berdasarkan analisis bivariat pada variabel bebas (media poster) dengan 
variabel terikat (perilaku penjamah makanan) akan diketahui seberapa efektif variabel bebas dalam meningkatkan variabel terikat. Data variabel terikat didapatkan dengan menggunakan form check list ketaatan perilaku yang sudah melalui uji ahli. Tidak ada variable penggangu sehingga tidak ada variable yang perlu dikontrol.

Pertama, melakukan uji normalitas dengan menggunakan uji Shapiro wilk. Kemudian melakukan uji statistik dengan menggunakan uji T-test Dependent. Jika data tidak berdistribusi normal, maka dilakukan uji statistik dengan menggunakan uji Wilcoxon. Tingkat kepercayaan yang digunakan yaitu $95 \%$ dengan batas kemaknaan $\mathrm{P}<0,05$.

\section{HASIL DAN PEMBAHASAN}

Penelitian dilakukan selama 2 bulan.

Pada bulan pertama dilakukan pretest kepada penjamah makanan di 10 stand makanan. Dilanjutkan dengan pemasangan 3 poster penelitian di dalam stand yang startegis, seperti di dekat wastafel untuk cuci tangan, di samping kiri dekat lemari atau sink dan di dekat penjamah melakukan pengolahan. Sehingga poster dapat menarik perhatian subyek. Poster dibiarkan selama 2 bulan untuk intervensi dan perilaku penjamah makanan diamati 2-3 kali perminggu selama intervensi. Setelah masa intervensi selesai, dilakukan posttest kepada 14 penjamah makanan yang menjadi responden.

\section{Karakteristik Responden}

Tabel 1: Distribusi Karakteristik Responden

\begin{tabular}{|c|c|c|c|}
\hline \multicolumn{2}{|c|}{ Variabel } & $\mathbf{n}$ & $\%$ \\
\hline \multirow{2}{*}{ Jenis kelamin } & Perempuan & 11 & 78,6 \\
\hline & Laki-laki & 3 & 21,4 \\
\hline Umur (tahun) & Mean \pm SD & \multicolumn{2}{|c|}{$46,93 \pm 7,79$} \\
\hline \multirow{5}{*}{ Pendidikan terakhir } & Tidak sekolah & 1 & 7,1 \\
\hline & SD & 0 & 0 \\
\hline & SMP & 4 & 28,6 \\
\hline & SMA & 7 & 50 \\
\hline & Perguruan tinggi & 2 & 14,3 \\
\hline \multirow{3}{*}{ Lama bekerja } & $1-5$ tahun & 8 & 57,14 \\
\hline & 6-10 tahun & 2 & 14,28 \\
\hline & 11-15 tahun & 4 & 28,57 \\
\hline \multirow{2}{*}{ Sertifikat Kesehatan } & Ya & 0 & 0 \\
\hline & Tidak & 14 & 100 \\
\hline \multirow{2}{*}{ Pernah mengikuti pelatihan } & $\mathrm{Ya}$ & 4 & 28,6 \\
\hline & Tidak & 10 & 71,4 \\
\hline
\end{tabular}


Berdasarkan tabel 1. diketahui bahwa penjamah makanan sebagian besar perempuan $(78,6 \%)$. Perempuan biasanya lebih baik dalam mengatur kebersihan, lebih sudah menerima informasi, dan lebih telaten dibandingkan laki-laki. Perempuan lebih baik

dalam hal tanggung jawab kesehatan daripada laki-laki (Shaheen, 2015).

Penjamah makanan rata-rata memiliki umur 46 tahun. Umur penjamah makanan sebagian besar masuk ke dalam kriteria usia lanjut (Depkes, 2009). Akan tetapi, umur tidak mempengaruhi seseorang dalam mendapatkan dan menerima informasi. Bertambahnya umur seseorang dapat berpengaruh terhadap tingkat pengetahuan yang diperoleh, sedangkan pada usia lanjut tingkat pengetahuan seseorang dapat berkurang. Usia lebih muda cenderung menggunakan gaya hidup yang lebih sehat daripada usia yang lebih tua (Shaheen, 2015).

Setengah dari jumlah penjamah makanan memiliki tingkat pendidikan terakhir SMA (50\%) dan penjamah makanan di sana sebagian besar bekerja selama 1-5 tahun $(57,14 \%)$. Pendidikan responden yang sebagian besar adalah SMA dan lama bekerja dalam rentang 1-5 tahun menandakan pengetahuan responden tidak hanya didapatkan dari pendidikan formal saja, tapi juga dari pengalaman kerja. Tingkat pengetahuan dipengaruhi oleh pendidikan seseorang (Budiman, 2012). Pendidikan penjamah makanan yang sebagian besar lulusan SMA, maka sebagian besar berpengetahuan baik, namun belum tentu baik dalam mengubah perilakunya. Pendidikan yang tinggi akan mempermudah seseorang menganalisis kondisi yang dihadapi, seperti perilaku yang baik sebagai penjamah makanan (Budiyono dkk., 2009). Lamanya bekerja atau pengalaman penjamah makanan akan mempengaruhi perilaku penjamah makanan (Fatmawati dkk., 2013).

Penjamah makanan yang tidak pernah mengikuti pelatihan yaitu 10 responden $(71,4 \%)$. Pelatihan maupun penyuluhan berperan besar terhadap perubahan perilaku akibat dari adopsi informasi yang didapat seseorang baik secara cepat maupun lambat (Budiyono dkk., 2009). Terdapat 4 orang penjamah makanan lainnya yang pernah mengikuti pelatihan yaitu seperti tata cara memperlakukan makanan dan bahan makanan yang baik dan benar. Sebuah penelitian juga menunjukkan bahwa responden yang pernah mengikuti seminar keamanan pangan memiliki kebiasaan membaca informasi kesehatan yang lebih baik (Puspaningtyas dkk., 2018). Selain 
hanya sedikit penjamah makanan yang pernah mengikuti pelatihan, diketahui pula bahwa semua penjamah makanan tidak memiliki sertifikat kesehatan.

\section{PERILAKU PENJAMAH MAKANAN}

Tabel 2: Perilaku Penjamah Makanan
Padahal dengan adanya sertifikat kesehatan mereka tahu bagaimana kondisi kesehatan mereka.

\begin{tabular}{lcccc} 
& \multicolumn{2}{c}{ Pretest } & \multicolumn{2}{c}{ Posttest } \\
\hline Perilaku & Frekuensi & Presentase & Frekuensi & presentase \\
\hline Positif & 14 & 100 & 14 & 100 \\
\hline Negatif & 0 & 0 & 0 & 0 \\
\hline Total & 14 & 100 & 14 & 100 \\
\hline
\end{tabular}

Berdasarkan pengamatan yang Berdasarkan pengkategorian menurut dilakukan selama 2 bulan diketahui bahwa Azwar (2011), seseorang dikatakan penjamah makanan di kantin Politeknik L/ berperilaku positif apabila memiliki nilai Negeri Jember berperilaku positif. $>50 \%$.

Tabel 3: Hasil Perbandingan Perilaku Penjamah Makanan Sebelum dan Sesudah Pemberian Poster

\begin{tabular}{ll|lll|l} 
& $\mathrm{n}$ & Min & Max & Mean \pm SD & $\mathrm{p}$ \\
\hline Sebelum & 14 & 52 & 88 & $72,70 \pm 10,49$ & \multirow{2}{*}{0.9981} \\
\hline Sesudah & 14 & 64 & 82 & $72,71 \pm 6,789$ & \\
\hline
\end{tabular}

Pemberian poster tanpa penyuluhan Perubahan rata-rata perilaku ditujukan untuk terciptanya perubahan penjamah makanan di kantin sebelum dan perilaku penjamah makanan yang positif. sesudah diberikan poster tanpa Berdasarkan uji yang dilakukan yaitu penyuluhan masih dalam kisaran yang Paired t-test dengan taraf kemaknaan sama yaitu 72,70 dan 72,71. Angka ini $<0,05$ didapatkan nilai $\mathrm{p}=0,9981$. secara statistik tidak ada perubahan yang Diketahui bahwa Ho diterima dan $\mathrm{Hi}$ signifikan. Pada awalnya responden ditolak karena nilai sig. (p) lebih besar dari tertarik untuk melihat poster dan memicu alfa $(0,05)$. Jadi, dapat dikatakan bahwa tidak ada perbedaan efektivitas penggunaan poster tanpa penyuluhan antara perilaku sebelum dan sesudah intervensi. rasa ingin tahu. Namun, butuh waktu lama untuk berhasil diadopsi responden. Jika berhasil, maka perilaku akan langgeng, bahkan diterapkan seumur hidup (Yustisa dkk., 2014). Seperti yang dikatakan 
penelitian sebelumnya bahwa perilaku yang sudah cukup lama mereka terapkan tidak serta merta akan berubah terlebih hanya diberikan poster tanpa penyuluhan. Hal lain juga dikarenakan tidak ada keluhan langsung dari konsumen dan kejadian yang tidak diinginkan seperti kontaminasi (Rapiasih dkk., 2010).

Meskipun pendidikan terakhir penjamah makanan sebagian besar SMA, namun umur mereka sebagian besar berada pada kategori usia lanjut yang dimungkinkan sedikit mendapatkan pengetahuan. Terlebih dalam penelitian ini tidak menggunakan penyuluhan. Poster tidak merubah pengetahuan maupun perilaku, jika hanya diintervensikan sendirian. Perlu bahan tambahan media lain untuk mentransfer pesan dari poster. Sedangkan untuk memaksimalkan penggunaan poster dan agar poster lebih efektif perlu disertai sumber informasi lain, seperti presentasi singkat (Rowe dan Ilic, 2013). Pengalihan materi dari poster ke media elektronik lebih menguntungkan dalam segi penyampaian pesan. Jumlah informasi yang dibagikan juga lebih banyak. Responden lebih cenderung memperhatikan media elektronik daripada bahan visual yang lainnya (Saldana, 2014). 
Tabel 4: Hasil Tiap Komponen Perilaku Form Checklist Pretest Dan Posttest

\begin{tabular}{lcccccccc}
\multicolumn{1}{c}{ Perilaku } & \multicolumn{4}{c}{ Pretest } & \multicolumn{6}{c}{ Posttest } \\
\cline { 2 - 9 } & $\mathrm{Y}$ & $\%$ & $\mathrm{~T}$ & $\%$ & $\mathrm{Y}$ & $\%$ & $\mathrm{~T}$ & $\%$ \\
\hline Celemek dipakai pada saat bekerja & 5 & 35,7 & 9 & 64,3 & 3 & 21,4 & 11 & 78,6 \\
\hline Kuku dalam keadaan pendek dan bersih & 13 & 92,9 & 1 & 7,1 & 12 & 85,7 & 2 & 14,3 \\
\hline Menyediakan tempat mencuci tangan & 14 & 100 & 0 & 0 & 14 & 100 & 0 & 0 \\
\hline $\begin{array}{l}\text { Mencuci tangan dengan air bersih dan sabun } \\
\text { sebelum mengolah makanan }\end{array}$ & 12 & 85,7 & 2 & 14,3 & 14 & 100 & 0 & 0 \\
\hline Mencuci peralatan dengan air bersih dan sabun & 14 & 100 & 0 & 0 & 14 & 100 & 0 & 0 \\
\hline $\begin{array}{l}\text { Tidak menggaruk kepala pada saat di depan } \\
\text { makanan }\end{array}$ & 14 & 100 & 0 & 0 & 14 & 100 & 0 & 0 \\
\hline $\begin{array}{l}\text { Tidak meludah di tempat pencucian peralatan } \\
\text { makan dan di sembarang tempat }\end{array}$ & 13 & 92,9 & 1 & 7,1 & 14 & 100 & 0 & 0 \\
\hline $\begin{array}{l}\text { Tutup kepala (penutup rambut) dipakai pada } \\
\text { saat bekerja }\end{array}$ & 10 & 71,4 & 4 & 28,6 & 11 & 78,6 & 3 & 21,4 \\
\hline Tidak berbicara pada saat mengolah makanan & 8 & 57,1 & 6 & 42,9 & 8 & 57,1 & 6 & 42,9 \\
\hline Tidak menggunakan perhiasan selama bekerja & 9 & 64,3 & 5 & 35,7 & 7 & 50 & 7 & 50 \\
\hline $\begin{array}{l}\text { Tidak makan/mengunyah makanan pada waktu } \\
\text { bekerja }\end{array}$ & 13 & 92,9 & 1 & 7,1 & 10 & 71,4 & 4 & 28,6 \\
\hline Menutup luka/tidak memiliki luka & 11 & 78,6 & 3 & 21,4 & 11 & 78,6 & 3 & 21,4 \\
\hline Tidak bersin/batuk di hadapan makanan & 12 & 85,7 & 2 & 14,3 & 13 & 92,9 & 1 & 7,1 \\
\hline Sepatu tertutup dan berhak rendah & 0 & 0 & 14 & 100 & 0 & 0 & 14 & 100 \\
\hline $\begin{array}{l}\text { Menggunakan alat bantu dalam penyajian } \\
\text { makanan }\end{array}$ & 13 & 92,9 & 1 & 7,1 & 14 & 100 & 0 & 0 \\
\hline $\begin{array}{l}\text { Memisahkan tempat penyimpanan bahan } \\
\text { makanan mentah dan makanan jadi/matang }\end{array}$ & 12 & 85,7 & 2 & 14,3 & 14 & 100 & 0 & 0 \\
\hline \begin{tabular}{l} 
Menyediakan tempat sampah yang tertutup \\
\hline
\end{tabular} & 0 & 0 & 14 & 100 & 0 & 0 & 14 & 100 \\
\hline
\end{tabular}

Berdasarkan total nilai yang didapatkan, masing-masing responden mendapat nilai lebih dari 50\%. Hal itu berarti semua perilaku responden positif selama intervensi. Akan tetapi, berdasarkan masing-masing komponen perilaku yang tertera pada form checklist terdapat peningkatan, penurunan, dan stagnan perilaku penjamah makanan.

Pemakaian celemek pada saat pretest adalah 5 responden, sedangkan saat posttest hanya 3 responden. Hal ini dikarenakan mereka merasa terlalu ribet jika harus menggunakan celemek. Responden dengan kuku dalam keadaan pendek menurun. Hasil awal 13 responden menjadi 12 responden dengan keadaan kuku pendek. Saat wawancara bahkan ada yang mengatakan kukunya pendek, padahal dalam kenyataannya berkuku panjang. Responden yang menggunakan perhiasan juga mengalami penurunan. Hasil awal 9 responden menjadi 7 responden. Hal ini berarti responden yang menggunakan perhiasan meningkat. Sebanyak 13 responden tidak mengunyah makanan pada saat dilakukan pretest, tetapi mengalami penurunan saat posttest yaitu menjadi 10 responden. Mereka sering mencomot makanan sesuka hati 
pada waktu bekerja tanpa menggunakan alat bantu pula. Keempat aspek ini sebenarnya sudah tertera pada poster. Akan tetapi, mereka tidak mengindahkan dengan berbagai alasan, seperti perhiasan untuk alasan keindahan penampilan, terlalu ribet dengan celemek, dll.

Kelalaian penjamah makanan dalam menggunakan APD dan fasilitas yang kurang memadai menjadi hambatan dalam melaksanakan standar pelayanan higiene sanitasi. Hambatan ini perlu mendapatkan perhatian oleh pihak yang menaungi agar tercipta higiene sanitasi yang lebih baik (Hapsari dkk., 2018). Penelitian yang dilakukan di RSPI juga mengatakan bahwa penjamah makanan masih berperilaku tidak higienis. Masih ada penjamah makanan yang tidak menggunakan celemek (33,3\%), tidak memakai sepatu tertutup (96,5\%), tidak memakai penutup kepala $(71,9 \%)$ (Susanti dkk., 2016). Penelitian lain juga mengatakan masih banyak penjamah yang belum menerapkan perilaku yang baik sebagai penjamah makanan. Terdapat $66,7 \%$ penjamah makanan tidak menggunakan celemek; 33,3\% penjamah makanan dengan kuku tidak bersih dan pendek; berbicara saat mengolah makanan 83,3\%; dan tidak memakai sepatu $100 \%$ (Fatmawati dkk., 2013).
Hasil dari form checklist tidak hanya menunjukkan adanya penurunan perilaku dari baik menjadi buruk. Aspek cuci tangan dengan air bersih dan sabun sebelum mengolah makanan mengalami peningkatan. Total awal 12 responden menjadi 14 (100\%) responden melakukan cuci tangan dengan air bersih dan sabun sebelum mengolah makanan. Pemasangan poster cuci tangan di samping wastafel menjadi salah satu alasan mereka ingat untuk mencuci tangan. Aspek tidak meludah di tempat pencucian peralatan makan dan di sembarang tempat mengalami peningkatan. Total awal 13 responden menjadi 14 responden. Satu responden yang mengalami peningkatan ini merasa bahwa perilaku beliau memang perlu diperbaiki dan melakukannya dalam selang waktu intervensi tersebut. Pemakaian penutup kepala juga mengalami peningkatan dari 10 responden menjadi 11 responden. Terdapat 3 responden yang tidak mengalami perubahan perilaku berjenis kelamin lakilaki. Mereka merasa terlalu ribet jika menggunakan penutup kepala. Aspek tidak bersin/batuk di hadapan makanan juga mengalami peningkatan dari 12 responden menjadi 13 responden. Aspek yang tertera pada poster ini juga membuat mereka lebih tahu bagaimana tindakan 
yang benar saat batuk/bersin. Pada aspek menggunakan alat bantu dalam penyajian makanan juga mengalami peningkatan dari 13 responden menjadi 14 responden. Meskipun aspek ini tidak tertera pada poster, kesadaran responden ternyata meningkat. Begitu juga dengan memisahkan tempat penyimpanan bahan makanan mentah dan makanan jadi/matang. Hasil yang didapatkan meningkat dari 12 responden menjadi 14 responden. Aspek terakhir yang mengalami peningkatan ini juga tidak tertera pada poster, tetapi responden meningkat kesadarannya.

Penjamah makanan berhubungan langsung dengan makanan mulai dari tahap persiapan, pembersihan, pengolahan, pengangkutan atau pendistribusian, hingga penyajian (Meliala, 2018). Mencuci tangan sebelum bekerja dan sesudah keluar dari kamar kecil, mengalihkan atau memalingkan muka ketika bersin atau batuk dari makanan, minuman, dan peralatannya, tidak menjamah makanan yang sudah masak dengan tangan langsung merupakan perilaku yang memang harus dimiliki oleh seorang penjamah makanan (Aritonang, 2014).

Penelitian yang dilakukan di Yogyakarta menunjukkan bahwa terdapat
$13(100 \%)$ responden patuh terhadap standar pelayanan makanan. Standar yang dimaksud yaitu meliputi higiene penjamah makanan, penyajian dan penanganan makanan, dll. Faktor yang berpengaruh terhadap kepatuhan responden tersebut yaitu motivasi (Hapsari dkk., 2018). Penjamah makanan di kantin Politeknik Negeri Jember ini juga memiliki motivasi masing-masing hingga mampu meningkatkan perilakunya dari yang kurang menjadi baik pada beberapa aspek. Berdasarkan hasil form checklist ini diketahui terdapat 7 aspek yang tidak mengalami perubahan. Sebanyak 2 aspek terdapat pada poster, tapi tidak mengalami perubahan. Sedangkan 5 aspek lainnya yang tidak mengalami perubahan tidak terdapat pada poster. Ketiadaan aspek tersebut pada poster dimungkinkan menjadi salah satu alasan responden tidak merubah perilakunya. Seperti penelitian di katering "X" Jakarta yang mengatakan bahwa ketidaktahuan penjamah makanan tentang kebersihan diri akan meningkatkan risiko kontaminasi antara penjamah dengan makanan (Nuraini dan Susanna, 2014). Kurangnya aspek yang tertera pada poster sebagai bahan evaluasi harus ada kesamaan antara aspek yang tertera pada form checklist dan poster. Kurangnya sarana dan prasarana juga 
berpengaruh pada penjamah makanan dalam merubah perilakunya. Hal ini dikarenakan sarana dan prasarana juga merupakan faktor pendukung yang berpengaruh terhadap terwujudnya perilaku sehat (Notoatmodjo, 2010).

Lamanya bekerja tidak menjamin penjamah makanan berperilaku baik. Begitu pula dengan pengalaman mengikuti penyuluhan atau pelatihan tidak menjamin penjamah makanan merubah perilakunya menjadi baik. Beberapa responden yang sudah pernah mengikuti penyuluhan tidak menjamin ketaatan dalam pengaplikasian informasi yang ada di dalam poster. Faktor lain yang berpengaruh lebih kuat dari pengetahuan terhadap perilaku seperti kebiasaan penjamah makanan, pengalaman yang masih sedikit, dan belum pernah mengikuti pelatihan (Fatmawati dkk., 2013).

Beberapa hambatan dalam komunikasi kesehatan termasuk di dalamnya penyampaian informasi untuk merubah perilaku menjadi lebih baik seperti kurangnya penerimaan dari responden, pesan yang kurang jelas, dan umpan balik yang kurang (Achalu, 2008). Responden dimungkinkan juga sulit dalam memahami pesan dari poster karena literasi yang kurang baik. Selain itu juga karena kemampuan pemahaman komunikasi yang buruk (Nkanunye dan Obiechina, 2017). Pemberian poster tanpa penyuluhan ini membuktikan bahwa 50\% dari aspek yang terdapat pada form checklist tidak mengalami perubahan, 4 aspek mengalami penurunan, dan 6 aspek mengalami peningkatan perilaku dari buruk menjadi baik. Seperti penelitian yang dilakukan di katering " $X$ " Jakarta yang mengatakan bahwa bukan hanya faktor pengetahuan yang mempengaruhi perilaku penjamah makanan. Di samping faktor media poster dan pengetahuan, dimungkinkan masih ada faktor lain yang lebih kuat seperti kebiasaan penjamah makanan dalam mengolah makanan, lingkungan yang kurang mendukung, pengalaman bekerja, dan belum pernah mengikuti pelatihan (Nuraini dan Susanna, 2014).

\section{Kesimpulan dan Saran}

\section{Kesimpulan}

Berdasarkan hasil penelitian dan analisis tentang efektivitas penggunaan poster terhadap perubahan perilaku penjamah makanan di kantin Politeknik Negeri Jember dapat disimpulkan bahwa tidak ada perubahan perilaku yang bermakna antara sebelum dan sesudah pemberian poster selama 2 bulan tanpa penyuluhan. Akan tetapi, berdasarkan 
masing-masing aspek pada form checklist terdapat perubahan perilaku sebelum dan sesudah pemberian poster. Dari 17 aspek, sebanyak 6 aspek mengalami kenaikan atau perubahan dari perilaku buruk menjadi baik. Empat aspek mengalami penurunan dan 7 aspek tidak mengalami perubahan.

Pada penelitian ini poster sebagai media tunggal tidak efektif dalam merubah perilaku penjamah makanan dari keseluruhan aspek. Dilihat dari media poster sendiri tidak ada permasalahan. Namun, memang diperlukan penjelasan seperti presentasi singkat atau penyuluhan agar penjamah makanan merubah perilakunya. Di samping itu, masyarakat juga sudah mulai bergeser dari memperhatikan media cetak ke media elektronik. Sehingga, media poster dapat digantikan dengan media elektronik untuk mencapai perubahan perilaku yang diinginkan.

\section{Saran}

1. Diharapkan untuk Dharma Wanita Politeknik Negeri Jember yang menaungi kantin utama memiliki program penyuluhan maupun pelatihan untuk penjamah makanan di kantin tersebut. Hal ini dikarenakan pemberian poster saja tidak efektif dalam merubah perilaku penjamah makanan untuk menerapkan perilaku baik.

2. Sebaiknya validasi media tidak dilakukan pada 1 validator saja dan harus sinkron antara komponen form yang digunakan dengan komponen yang ada pada poster.

\section{Ucapan Terima Kasih}

Untuk segala pihak yang telah membantu penelitian ini saya ucapkan banyak terimakasih. Rampungnya penelitian ini juga atas kerjasama berbagai pihak dan elemen masyarakat yang berbaik hati. Semoga Allah SWT. membalas segala kebaikan dengan berkah yang melimpah.

\section{Daftar Pustaka}

Achalu, EI. 2008. Communication skills in Health Education and Public Health: Methods \& Resources. Port Harcourt: PamUnique.

Aritonang, I. 2014. Penyelenggaraan Makanan. Yogyakarta: Leutikabooks.

Azwar, S. 2011. Sikap dan Perilaku. Sikap Manusia Teori dan Pengukurannya (Edisi 2). Yogyakarta: Pustaka Pelajar.

Badan Pengawas Obat dan Makanan (BPOM). 2017. Kinerja Badan Pengawas Obat Dan Makanan Dalam Angka Triwulan III Tahun $2017 . \quad$ (serial online). http://www.pom.go.id/ppid/ 
2015/rtn2017tw3.pdf. $\quad$ (17 Juli 2018).

Budiman, Santi. 2012. Analysis of Consumer Attitudes to Purchase Intentions of Counterfeiting Bag Product in Indonesia. International Journal of Management, Economics and Social Sciences, 1(1), pp.112.(serial online). http://www.ijmess.com/volumes/vo lume-I-2012/issue-I-05-2012/full1.pdf . (23 Januari 2019).

Budiyono, B., I. Isnawati, dan T. Wahyuningsih. 2009. Tingkat pengetahuan dan praktik penjamah makanan tentang hygiene dan sanitasi makanan pada warung makan di Tembalang Kota Semarang tahun 2008. Jurnal Promosi Kesehatan Indonesia, 4(1), pp.50-60.

Departemen Kesehatan Republik Indonesia (Depkes RI). 2009. Kategori Umur. Jakarta: Departemen Kesehatan Republik Indonesia (Depkes RI).

Fatmawati, S., A. Rosidi, dan E. Handarsari. 2013. Perilaku Higiene Pengolah Makanan Berdasarkan Pengetahuan Tentang Higiene Mengolah Makanan Dalam Penyelenggaraan Makanan Di Pusat Pendidikan Dan Latihan Olahraga Pelajar Jawa Tengahari, Erma. Jurnal Gizi Universitas Muhammadiyah Semarang, 2(2), pp. 30-38.

Hapsari, O.P., I. Permana, E. Listiowati. 2018. Analisis Praktik Higiene Sanitasi Karyawan Instalasi Gizi Studi Kasus Di Rumah Sakit Swasta Yogyakarta.

Jurnal
Medicoeticolegal dan Manajemen Rumah Sakit, 7, pp.1-7.

Meliala, E.L.B. 2018. Perilaku Hygiene Dan Sanitasi Makanan Ditinjau Dari Aspek Penjamah Makanan (Foodhandler) Di Rc (Retreat Center) Sukamakmur Tahun 2017. Skripsi. Medan: Politeknik Kementrian Kesehatan Medan.

Nkanunye, C.C. dan G.O. Obiechina. 2017. Health Communication Strategies as Gateway to Effective Health Promotionand Well-being. Journal of Medical Research and Health Education, 1(3), pp.1-4. (serial online). http://www.imedpub.com/medicalresearch-and-health-education/. (23 Januari 2019).

Notoatmodjo, S. 2010. Ilmu Perilaku Kesehatan. Jakarta: Rineka Cipta.

Nuraini, P. dan D. Susanna. 2014. Karakteristik dan pengetahuan penjamah makanan dengan perilaku tentang higiene perorangan pada proses pengolahan makanan di katering "x" jakarta tahun 2014. FKM UI.

Onyeneho, S. N. and Hedberg, C. W. 2013. An assessment of food safety needs of restaurants in Owerri, Imo State, Nigeria. International journal of environmental research and public health, 10(8), pp. 3296-3309. (serial online). http://www.mdpi.com/16604601/10/8/3296/htm. doi: 10.3390/ ijerph10083296. (09 Maret 2018).

Puspaningtyas, D.E., M. Iqbal, N.A. Choiriyah, I.Y. Setyorini. 2018. Food label reading habit in Indonesian nutrition student: multistrata comparison review. (serial 
online).

https://publikasi.polije.ac.id/index.p hp/ProceedingICOFA/article/view/ 1304. (07 Juli 2019).

Rahmaniati, R. 2015. Penggunaan Media Poster Untuk Meningkatkan Hasil Belajar IPA Peserta Didik Kelas VB SDN 6 Langkai Palangka Raya. Pedagogik Jurnal Pendidikan, 10(2), pp. 59-64. (serial online).

Rapiasih, N.W., Y. Prawiningdyah, dan L.A. Lestari. 2010. Pelatihan hygiene sanitasi dan poster berpengaruh terhadap pengetahuan, perilaku penjamah makanan, dan kelaiakan hygiene sanitasi di instalasi gizi RSUP Sanglah Denpasar. Jurnal Gizi Klinik Indonesia, 7(2), pp.64-73. (serial online).

https://journal.ugm.ac.id/jgki/ article/view/17738. (31 Maret 2018).

Rowe, N.E. dan Ilic D. 2013. What is the evidence that poster presentations are effective in promoting knowledge transfer? A state of the art review. Health Info Libr J, 30, pp.4-12.

Saldana, R. A. 2014. Assessing the Effectiveness of Health Educational Posters in Community Health Centers. Primary Care Leadership Program, pp.1-31. (serial online).

Shaheen, A.M., Nassar, O.S., Amre, H.M. dan Hamdan-Mansour, A.M. 2015. Factors Affecting Health-Promoting Behaviors of University Students in Jordan. Health, 7, pp.1-8. (serial online). http://dx.doi.org/10.4236/ health.2015.71001. (23 Januari 2019).
Siau, A.M.F., Son, R., Mohhiddin, O., Toh, P.S. and Chai, L.C. 2015. Food court hygiene assessment and food safety knowledge, attitudes and practices of food handlers in Putrajaya. International Food Research Journal, 22(5), pp.1843.

Susanti, I., N. Hendrawati, T. Sundari, M.M. Montain. 2016. Profil Kepatuhan Higiene Perorangan Penjamah Makanan di Instalasi Gizi dan Tata Boga Rumah Sakit Penyakit Infeksi (RSPI) Prof. Dr. Sulianti Saroso. The Indonesian Journal of Infectious Disease, pp.19-28. (serial online). https://www.google.com/url?sa=t\& $\mathrm{rct}=\mathrm{j} \& \mathrm{q}=\& \mathrm{esrc}=\mathrm{s} \&$ source $=$ web\&cd $=3 \&$ cad $=$ rja \&uact $=8 \&$ ved $=2$ ahUK EwiD983pgJnjAhXX73MBHYMn ARAQFjACegQIABAB\&url=https $\% 3 \mathrm{~A} \% 2 \mathrm{~F} \% 2 \mathrm{Fwww}$.neliti.com\%2Fi d\%2Frspi-prof-drsuliantisaroso\&usg=AOvVaw0Ib5e tTyhIJiJNYsQvmQZJ. (27 Juni 2019).

Syafirah, S. dan D.R Andrias. 2017. Higiene Penjamah Makanan Dan Sanitasi Kantin Sekolah Dasar Negeri Di Kecamatan Mulyorejo, Surabaya. Media Gizi Indonesia, 10(2), pp. 111-116. (serial online). http://e-journal. unair.ac.id/index.php/MGI/article/v iew/3314/2358. (25 Februari 2018).

Yustisa P.F., I.K. Aryana, dan I.N.G. Suyasa. 2014. Efektivitas penggunaan media cetak dan media elektronika dalam promosi kesehatan terhadap peningkatan pengetahuan dan perubahan sikap siswa SD. Jurnal Kesehatan Lingkungan, 4(1), pp.29-39. (serial online). 